\title{
Inbred mouse strains $\mathrm{C57BL/6J}$ and DBA/2J vary in sensitivity to a subset of bitter stimuli
}

\author{
John D Boughter Jr*1, Sandeep Raghow ${ }^{1}$, Theodore M Nelson ${ }^{2}$ and \\ Steven D Munger ${ }^{2,3}$
}

Address: ${ }^{1}$ Anatomy and Neurobiology, University of Tennessee Health Science Center, Memphis, TN 38163 USA, ${ }^{2}$ Anatomy and Neurobiology, University of Maryland School of Medicine, Baltimore, MD 21201, USA and Program in Neuroscience, University of Maryland School of Medicine, Baltimore, MD 21201, USA

Email: John D Boughter* - jboughter@utmem.edu; Sandeep Raghow - sraghow1@utmem.edu; Theodore M Nelson - tnels002@umaryland.edu; Steven D Munger - smung001@umaryland.edu

* Corresponding author

Published: 20 June 2005

BMC Genetics 2005, 6:36 doi:10.1/86/147/-2156-6-36
Received: 04 February 2005

Accepted: 20 June 2005

This article is available from: http://www.biomedcentral.com/I47I-2I56/6/36

(c) 2005 Boughter et al; licensee BioMed Central Ltd.

This is an Open Access article distributed under the terms of the Creative Commons Attribution License (http://creativecommons.org/licenses/by/2.0), which permits unrestricted use, distribution, and reproduction in any medium, provided the original work is properly cited.

\begin{abstract}
Background: Common inbred mouse strains are genotypically diverse, but it is still poorly understood how this diversity relates to specific differences in behavior. To identify quantitative trait genes that influence taste behavior differences, it is critical to utilize assays that exclusively measure the contribution of orosensory cues. With a few exceptions, previous characterizations of behavioral taste sensitivity in inbred mouse strains have generally measured consumption, which can be confounded by post-ingestive effects. Here, we used a taste-salient brief-access procedure to measure taste sensitivity to eight stimuli characterized as bitter or aversive in C57BL/6J (B6) and DBA/2J (D2) mice.

Results: $\mathrm{B} 6$ mice were more sensitive than D2 mice to a subset of bitter stimuli, including quinine hydrochloride (QHCl), 6-n-propylthiouracil (PROP), and $\mathrm{MgCl}_{2}$. D2 mice were more sensitive than B6 mice to the bitter stimulus raffinose undecaacetate (RUA). These strains did not differ in sensitivity to cycloheximide (CYX), denatonium benzoate (DB), $\mathrm{KCl}$ or $\mathrm{HCl}$.

Conclusion: B6-D2 taste sensitivity differences indicate that differences in consumption of $\mathrm{QHCl}$, PROP, $\mathrm{MgCl}_{2}$ and RUA are based on immediate orosensory cues, not post-ingestive effects. The absence of a strain difference for CYX suggests that polymorphisms in a T2R-type taste receptor shown to be differentially sensitive to CYX in vitro are unlikely to differentially contribute to the CYX behavioral response in vivo. The results of these studies point to the utility of these common mouse strains and their associated resources for investigation into the genetic mechanisms of taste.
\end{abstract}

\section{Background}

The majority of heritable traits in humans and other species are complex in nature, determined by interactions among multiple genes and environmental factors. Mouse genetic models have been critical in identifying genes that determine complex behavioral traits (e.g., [1-3]). The standard inbred strains C57BL/6J (B6) and DBA/2J (D2) have played a key role in mouse genetics, and they are among the strains included in the public and private genome sequencing projects. $\mathrm{BXD} / \mathrm{Ty}(\mathrm{BXD})$ recombinant inbred (RI) mice, created from $\mathrm{B} 6$ and $\mathrm{D} 2$ progenitors, have been used to identify and map quantitative trait loci 
(QTLs) that influence diverse phenotypes such as addictive behavior (e.g., [4-6]), lifespan [7], central nervous system anatomy [8-10], and solution consumption [11-13]. Recently, the BXD set has been expanded to about 80 strains, which makes it the largest mouse RI mapping panel and a useful resource for QTL analysis [14].

The characterization of behavioral taste sensitivity in $\mathrm{B} 6$ and D2 mice would facilitate the use of BXD mice in mapping QTLs for taste sensitivity (). B6 mice have been the most common inbred strain used in gustatory research, and as such have been characterized in terms of one- and two-bottle intake, brief-access taste sensitivity, operant taste detection tasks, taste discrimination, gustatory nerve physiology, taste receptor cell physiology, and taste cellspecific gene expression (e.g., [15-23]. D2 mice have not been as thoroughly characterized (e.g., [23-25]. However, it has long been appreciated that significant differences between $\mathrm{B} 6$ and D2 mice exist for consumption of sweetand bitter-tasting stimuli, ethanol, and sodium chloride [26-29].

For stimuli characterized by humans as possessing a bitter taste, B6 and D2 mice vary in level of responsiveness when queried with intake tests: concentration-dependent strain differences have been measured for the typical bitter stimulus quinine hydrochloride ( $\mathrm{QHCl} ;[22,28])$, acetylated sugars such as raffinose undecaacetate (RUA; $[11,30]$ ), and copper glycinate [13]. Such two-bottle intake procedures have been manageable for testing the large numbers of mice required for quantitative analysis. However, it is questionable whether these tests provide valid indicators of an animal's ability to recognize or discriminate a substance based on gustatory cues. Bitter stimuli comprise an exceptionally diverse set of chemical compounds that vary greatly in toxicity (e.g., [31,32]). Our recent study [33] demonstrates that post-ingestive effects related to bitter stimulus toxicity directly influence results from two-bottle tests and that these effects are considerably minimized in brief-access tests. Here we describe the use of a taste-salient brief-access procedure (e.g., $[16,33,34]$ to characterize taste sensitivity in B6 and D2 mice to eight stimuli: six which are perceived by humans as predominantly bittertasting (QHCl, 6-n-propylthiouracil (PROP), $\mathrm{MgCl}_{2}$, RUA, denatonium benzoate (DB), and cycloheximide $(\mathrm{CYX}))$, one with a complex salt/bitter taste $(\mathrm{KCl})$, and an acid $(\mathrm{HCl})$. These studies demonstrate that $\mathrm{B} 6$ and $\mathrm{D} 2$ mice differ in taste sensitivity to some, but not all, bitter or aversive stimuli, and suggest that they will be a useful resource for characterizing the genetic basis of bitter taste.

\section{Results \\ Response to bitter and acid stimuli}

Thirty B6 and 30 D2 mice were tested with six concentrations each of three different stimuli, such that a total of $\sim$
10 mice of each strain were tested for each of eight stimuli (Table 1; QHCl, PROP, $\mathrm{MgCl}_{2}$, RUA, DB, CYX, $\mathrm{KCl}$, and $\mathrm{HCl}$ ). Concentration-response functions were created for individual mice (for all compounds) and were fitted with two-parameter logistic functions, so that the concentration evoking half-maximal avoidance $(c)$ could be determined. Examples of such individual functions for $\mathrm{QHCl}$ in B6 and D2 mice are shown in Figures 1 and 2, respectively. All B6 mice displayed concentration-dependent avoidance of $\mathrm{QHCl}$ (Fig. 1). Estimated half-maximal avoidance $(c)$ ranged from 0.09 to $1.0 \mathrm{mM} \mathrm{QHCl}$ among individual mice, but there was not a significant difference between the six mice tested with $\mathrm{QHCl}$ as the first stimulus versus the four that were tested with $\mathrm{QHCl}$ as the third stimulus. Estimated half-maximal avoidance of $\mathrm{QHCl}$ among individual D2 mice ranged from 0.27 to $3.07 \mathrm{mM}$. For all but one D2 mouse (D105; Fig. 2), $c>1.15 \mathrm{mM}$. Some of the D2 mice such as D98, D97 and D82 showed relatively little avoidance of the higher concentrations of $\mathrm{QHCl}$. As was the case for B6 mice, $c$ did not vary significantly among individual mice as a function of whether the QHCL was presented as the first or last stimulus in the test series (D98 was not included in this comparison, because $c$ could not be accurately estimated. However, all B6 and D2 mice were used for repeated measures comparisons; see below). The average half-maximal avoidance was 0.41 $\mathrm{mM}$ for B6 mice and $1.75 \mathrm{mM}$ for D2 mice $[t(17)=4.33$; $p<0.001]$. Notably, comparisons of $c$ within strain for all eight stimuli did not reveal significant effects of test group (i.e. whether the stimulus was presented first, second or third in series; see Table 1) with a single exception, noted below. Data collected for each compound were therefore combined for analysis of potential strain and gender effects.

Strain differences in taste sensitivity were found for four of eight compounds: QHCl, PROP, $\mathrm{MgCl}_{2}$, and RUA (Figure 3). For $\mathrm{QHCl}, \mathrm{D} 2$ mice had significantly higher lick ratios than $\mathrm{B} 6$ mice across most of the concentration range, indicating decreased aversion. A strain $\mathrm{x}$ gender $\mathrm{x}$ concentration ANOVA revealed a main effect of strain $[F(1,16)=$ $16.64, \mathrm{p}<0.001$ ] but not gender. There was a significant strain $\mathrm{x}$ concentration interaction $[\mathrm{F}(5,80)=3.74$, $\mathrm{p}<$ $0.01]$. The strain $\mathrm{x}$ gender, or strain $\mathrm{x}$ gender $\mathrm{x}$ concentration interactions were not significant for $\mathrm{QHCl}$ (or for any of the 7 other stimuli). Planned comparisons (Least Squares means) between strain at each concentration revealed that D2 mice were significantly less sensitive ( $\mathrm{p}<$ 0.01 ) to $0.3-3 \mathrm{mM} \mathrm{QHCl}$.

Similarly, D2 mice were less sensitive to PROP: a strain x gender $\mathrm{x}$ concentration ANOVA revealed a main effect of strain $[\mathrm{F}(1,16)=10.5, \mathrm{p}<0.01]$ but not gender. There was a significant strain $x$ concentration interaction $[F(5,80)=$ 7.01, $\mathrm{p}<0.0001]$. Planned comparisons indicated D2 
Table I: Test compounds and test series for 30 B6 and 30 D2 mice. Each mouse was tested with three compounds (2 consecutive test sessions per compound) over a two-week period. Stimuli were $\mathrm{KCl}$, cycloheximide (CYX), raffinose undecaacetate (RUA), 6-n-propylthiouracil, quinine hydrochloride $(\mathrm{QHCl})$, denatonium benzoate (DB), and $\mathrm{HCl}$. $A$ total of 10 mice were tested from each strain $(5$ males, 5 females) for $\mathrm{KCl}, \mathrm{CYX}, \mathrm{PROP}, \mathrm{MgCl}_{2}$ and $\mathrm{QHCl}$. A total of 10 mice from each strain (5 males, 5 females for B6; 7 females, 3 males for D2) were tested with DB and $\mathrm{HCl}$. A total of I I B6 mice ( 6 females, 5 males) and 9 D2 mice (5 females, 4 males) were tested with RUA.

\begin{tabular}{llll}
\hline & & Number of Mice Tested & \\
\hline Squad & Compounds & B6 & D2
\end{tabular}

$\begin{array}{ll}\text { A } & \mathrm{KCl}, \mathrm{CYXl}^{\prime} \\ \text { B } & \mathrm{CYX}, \mathrm{RUA}, \mathrm{KCl} \\ \text { C } & \mathrm{PROP}, \mathrm{MgCl} 2, \mathrm{QHCl} \\ \text { D } & \mathrm{MgCl}, \mathrm{PROP}, \mathrm{QHCl} \\ \text { E } & \mathrm{DB}, \mathrm{HCl}^{2} \\ \text { F } & \mathrm{QHCl}, \mathrm{MgCl} 2, \mathrm{PROP} \\ \text { G } & \mathrm{HCl}, \mathrm{DB}, \mathrm{RUA} \\ & \\ & \text { Total Mice }\end{array}$

$\begin{array}{ll}5 & 5 \\ 5 & 5 \\ 2 & 3 \\ 2 & 2 \\ 4 & 6 \\ 6 & 5 \\ 6 & 4 \\ 30 & 30\end{array}$

\footnotetext{
1,2 In squads $A$ and $E$ additional data on a third aversive stimulus was collected but was treated as pilot data and not included as part of the current experiment.
}

mice possessed higher lick ratios at 3 and $10 \mathrm{mM}$. The mean half-maximal avoidance was $1.46 \mathrm{mM}$ for $\mathrm{B} 6$ mice and for $4.97 \mathrm{mM}$ for D2 mice $[t(17)=4.05 ; p<0.001]$.

For $\mathrm{MgCl}_{2}$, there was a main effect of strain $[\mathrm{F}(1,16)=$ $12.6, \mathrm{p}<0.01$ ] but not gender. Planned comparisons indicated D2 mice possessed significantly higher lick ratios at $0.003,0.1$ and $0.3 \mathrm{mM}$. A modest curve shift across the entire concentration range was not quite significant: mean half-maximal avoidance was $0.02 \mathrm{M}$ for $\mathrm{B} 6$ mice and 0.05 $\mathrm{M}$ for D2 mice $[t(17)=2.34 ; p=0.03]$.

For RUA, the direction of the strain difference was reversed. Notably, B6 mice did not display strong aversion to any concentration, whereas D2 mice avoided RUA in a concentration-dependent manner. There was a main effect of strain $[F(1,16)=39.56, p<0.0001]$ but not gender. A significant interaction was found for concentration $\mathrm{x}$ strain $[\mathrm{F}(5,80)=3.84, \mathrm{p}<0.01]$. Planned comparisons indicated $\mathrm{D} 2$ possessed greater avoidance than $\mathrm{B} 6$ mice at 0.005 , and at $0.03-0.3 \mathrm{mM}$. D2 mice actually possessed a greater level of avoidance to the lowest concentration of RUA $(0.005 \mathrm{mM})$ relative to the next two higher concentrations (0.01 and 0.03). This tendency was evident in eight of nine individual D2 mice (data not shown), although it is not clear why such an effect was found. The mean curve shift between strains was not examined for RUA due to the lack of concentration-dependent avoidance in $\mathrm{B} 6$ mice, and the resulting inability to estimate the $c$-parameter.

We did not detect strain or gender differences in sensitivity to $\mathrm{CYX}, \mathrm{DB}, \mathrm{KCl}$, or $\mathrm{HCl}$ (Figure 4). Both strains avoided higher concentrations of each of these stimuli in a concentration-dependent fashion. An effect on half-maximal avoidance based on test series was found for CYX: D2 mice that received CYX as the first stimulus tended to have a lower $c$ value $($ mean $=0.53 \mu \mathrm{M})$ than those that received it as the second stimulus (mean $=2.66 \mu \mathrm{M} ; p<0.01)$. A similar effect was found in the B6 mice, although not quite significant $(p=0.03)$. Testing each of these subgroups for significance with ANOVA (with $n=5$ / strain) showed that B6 and D2 still did not differ in level of aversion ( $\mathrm{p}>0.08$; however, small sample sizes in this comparison should be noted). Between conditions, lick ratios for both strains tended to differ modestly at 0.3 and $1 \mu \mathrm{M}$, but not at the higher concentrations $(3-100 \mu \mathrm{M})$. The cause of the within-strain curve shifts is unclear, although B6 and D2 mice did not differ significantly in sensitivity to this stimulus.

\section{Baseline licking, performance and latency}

Taste data were reported as lick ratios in order to standardize for possible strain differences in water lick rate $[16,33]$. We compared these "baseline" rates of water licking between B6 and D2 mice collapsed across all days of stimulus testing. B6 mice licked water at an average rate of 33.81 licks / $5 \mathrm{~s}$ whereas D2 licked at an average rate of 35.76 licks / $5 \mathrm{~s}$; this difference was not significant $[\mathrm{F}(1,58)=2.68 ; p>0.1]$. In addition to lick rate, we were also interested in examining other aspects of behavior in the task that are thought to be non-gustatory in origin. Performance was reported as percent trials completed per test session, per mouse. Table 2 lists mean performance rates for each strain, by gender, for each of three consecutive test sessions. In general, B6 mice of either gender tended to complete a slightly larger percentage of trials than did D2 mice $[F(1,52)=17.10, p<0.01]$. In order to account for possible effects of each unique stimulus on performance, we also examined this performance for each of the eight stimuli: There was still a significant main effect of strain $[F(1,147)=20.9 ; \mathrm{p}<0.001]$, although the effect for stimulus was not significant.

We asked if olfactory cues might contribute to avoidance in the brief-access test. We measured the latency to initiate trials for each compound, because concentration-dependent changes in latency have been suggested previously to indicate olfactory contribution [35]. Latencies for all stimuli are shown in Figure 5. A significant main effect of 

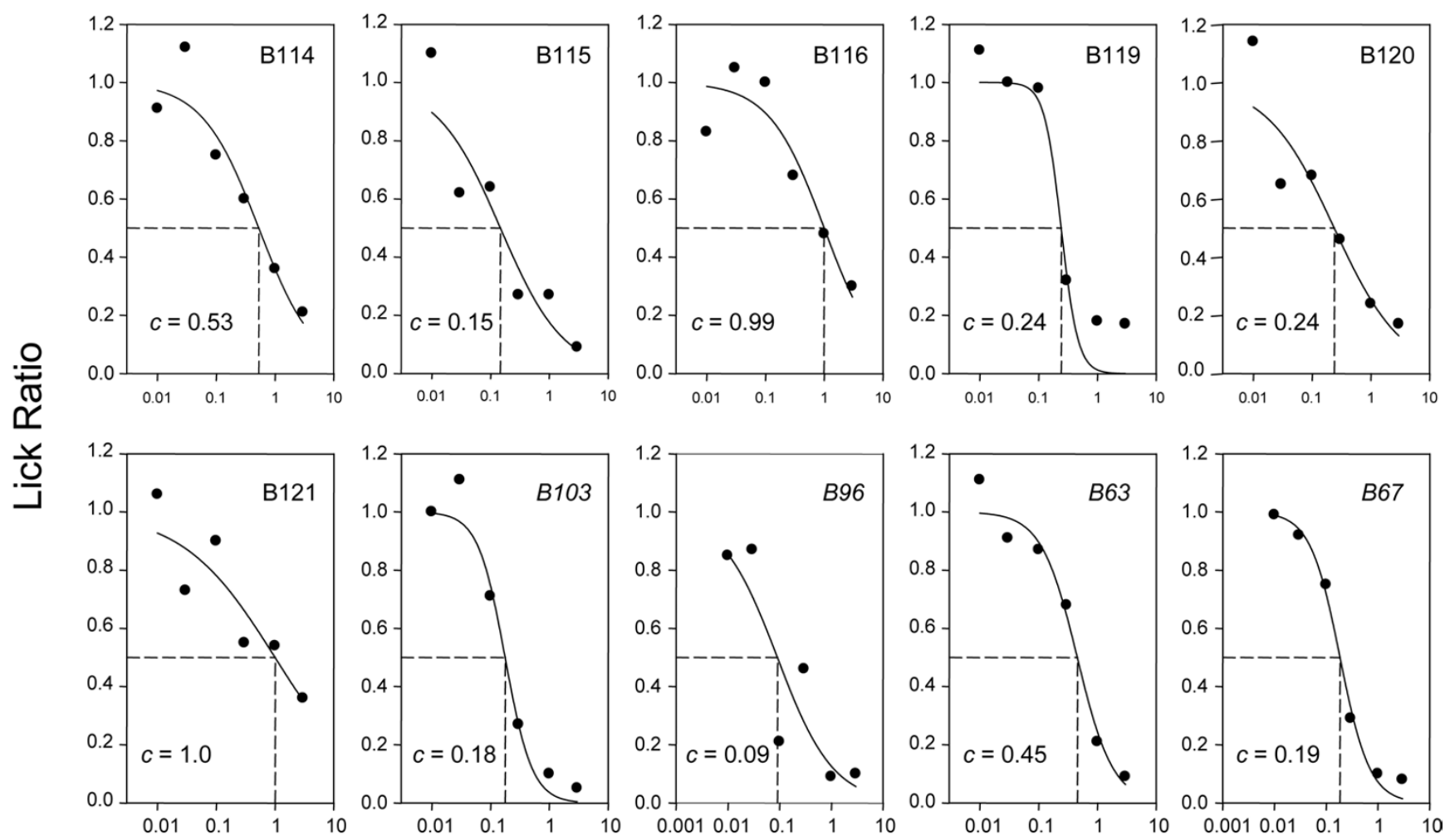

\section{$\mathrm{QHCl}$ concentration (mM)}

\section{Figure I}

Concentration-response functions quinine in 10 individual B6 mice. Data points for each mouse represent average ratios across two days of testing; these means were fitted with two-parameter logistic functions and the concentration evoking halfmaximal avoidance, $C$, was estimated. Italicized mice $(B / 03, B 96, B 93, B 67)$ were given $\mathrm{QHCl}$ as the last of three stimuli, as opposed to the others, which received $\mathrm{QHCl}$ as the first stimulus.

strain was found for only $\operatorname{KCl}[\mathrm{F}(1,160)=9.96, \mathrm{p}<0.01]$, whereas effects of concentration were significant for $\mathrm{DB}$ and $\mathrm{HCl}[\mathrm{F}(6,96)>3.4, \mathrm{p}<0.01]$. Only a single significant interaction was detected: Concentration $\mathrm{x}$ strain for RUA $[F(6,96=3.15 ; p<0.01]$. In general, greater latency was often observed for the highest concentration of a given stimulus. Latency to lick may increase as a function of olfactory cues, but it is important to consider that other strain differences such as overall activity levels may also affect this measure. Overall, reliable effects on latency to lick bitter stimuli in mice have not been reported $[33,34,36]$.

\section{Discussion}

Previous studies comparing the consumption of bitter stimuli in two or more standard inbred strains of mice have fostered genetic and molecular approaches towards identifying taste transduction mechanisms (e.g., $[11,12,28,37-39])$. Given the potential for which post- ingestive factors affect levels of intake of particular bitter stimuli [33], we were eager to assess taste sensitivity in the commonly used inbred strains B6 and D2 with a taste-salient brief-access assay. We demonstrated significant concentration-dependent differences in taste sensitivity to a subset of aversive compounds, including the bitter stimuli QHCl, PROP, $\mathrm{MgCl}_{2}$, and RUA. Strain differences were not found for CYX, KCl, DB, or HCl. These strains did not differ in baseline levels of water licking. Additionally, we did not find effects of gender on taste sensitivity.

The B6-D2 taste sensitivity differences demonstrated for $\mathrm{QHCl}$ and RUA indicate that differences in consumption of these stimuli between these strains $[22,28]$ are based on immediate orosensory cues. Our results are also consistent with a potential relationship between quinine and PROP aversion [37]. D2 mice displayed significantly less aversion than $\mathrm{B} 6$ mice to both $\mathrm{QHCl}$ and PROP; the strain differences were similar in magnitude (Fig. 4). The 

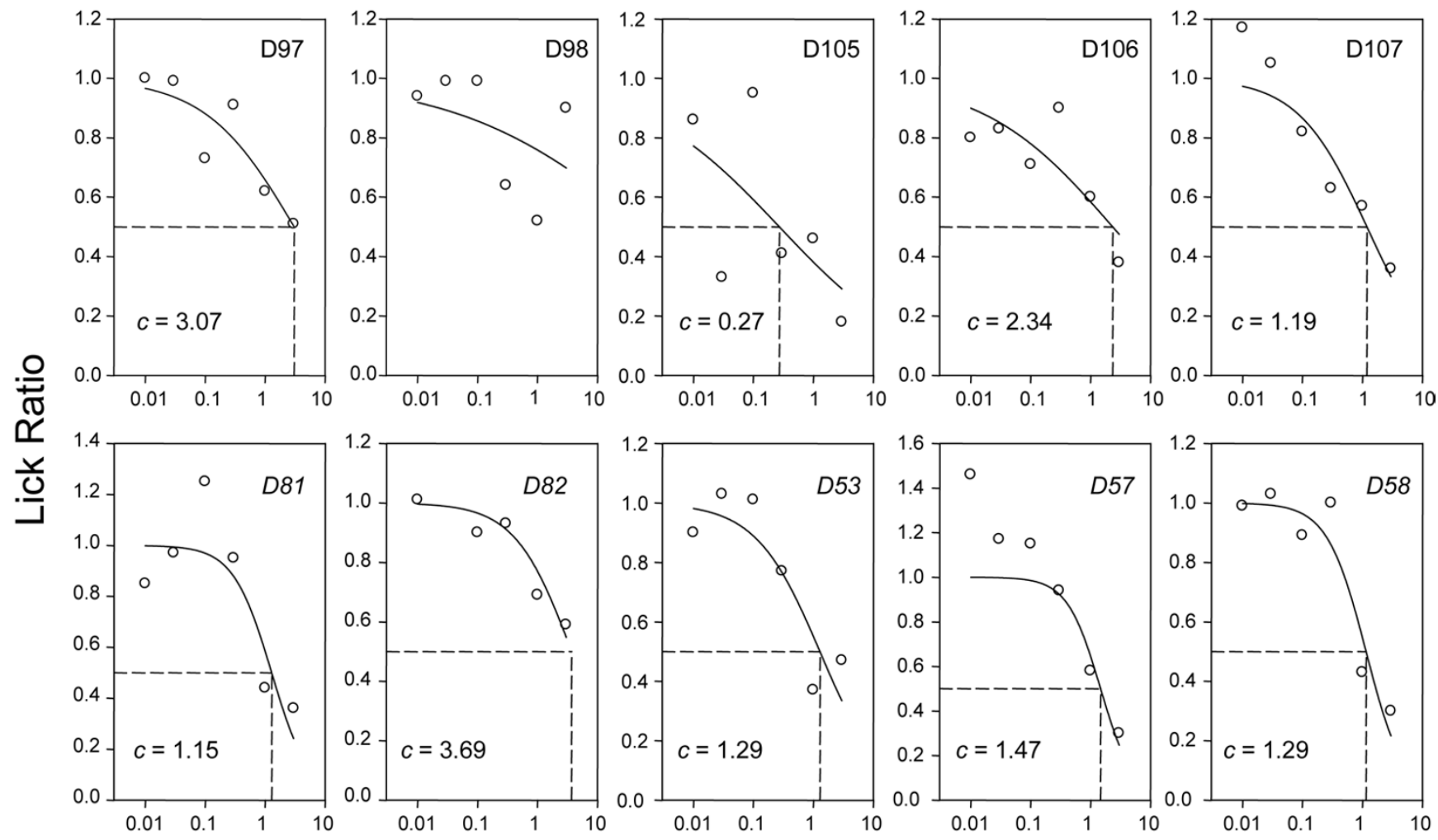

\section{$\mathrm{QHCl}$ concentration (mM)}

Figure 2

Concentration-response functions for $\mathrm{QHCl}$ in 10 individual $\mathrm{D} 2$ mice. Data points for each mouse represent average ratios across two days of testing; these means were fitted with two-parameter logistic functions and the concentration evoking halfmaximal avoidance, $c$, was estimated. For one mouse (D98) this parameter could not accurately estimated, although this mouse had a mean lick ratio of 0.52 for I $\mathrm{mM} \mathrm{QHCl}$. Italicized mice $(D 8 I, D 82, D 53, D 57, D 58)$ were given $\mathrm{QHCl}$ as the last of three stimuli, as opposed to the others which received $\mathrm{QHCl}$ as the first stimulus.

relationship between quinine and PROP taste sensitivity is surprising when one considers that, in contrast to the situation in humans, taste sensitivity to PROP in mice is not correlated with its structural analogue phenylthiocarbamide (PTC) [33].

Linkage studies have postulated a major locus controlling quinine intake, qui, closely linked to Prp2 and Prh1 (which encode two proline-rich salivary proteins) and the microsatellite marker D6Mit13 on distal mouse chromosome $6[21,37,40]$. Harder and Whitney [37] further showed, using BXH RI mice (bred from progenitor strains $\mathrm{B} 6$ and $\mathrm{C} 3 \mathrm{HeB} / \mathrm{HeJ}$ ), that PROP intake was also under $\mathrm{Chr}$ 6 control. The linkage of putative bitter taste receptor genes (Tas2rs) to these loci predicts that polymorphisms in particular Tas2rs underlie strain differences to these stimuli. However, the ligand specificity of these receptors is difficult to predict, given that only a handful of mouse or human bitter taste receptors have been functionally characterized, and that evidence for narrow or broad tuning is equivocal [41-43]. There is strong evidence for polygenic control of both $\mathrm{QHCl}$ and PROP intake based on quantitative genetic analyses $[15,37,44,45]$, and Tas $2 r$ independent mechanisms for $\mathrm{QHCl}$ taste have been suggested (e.g., $[46,47])$. A genetic analysis using the briefaccess assay may help to determine whether non-Tas $2 r$ genes contribute to quinine sensitivity based on immediate sensory cues ().

We also found that $\mathrm{D} 2$ mice were less sensitive for $\mathrm{MgCl}_{2}$, a compound not previously investigated in these strains. Interestingly, D2 mice licked the lowest concentration of $\mathrm{MgCl}_{2}(0.003 \mathrm{mM})$ at a rate greater than distilled water. We previously reported that $\mathrm{C} 3 \mathrm{HeB} / \mathrm{FeJ}$ inbred mice prefer 0.01 and $0.03 \mathrm{mM} \mathrm{MgCl}_{2}$ to water in a two-bottle intake test [33]. It is possible that water-deprived mice, as 


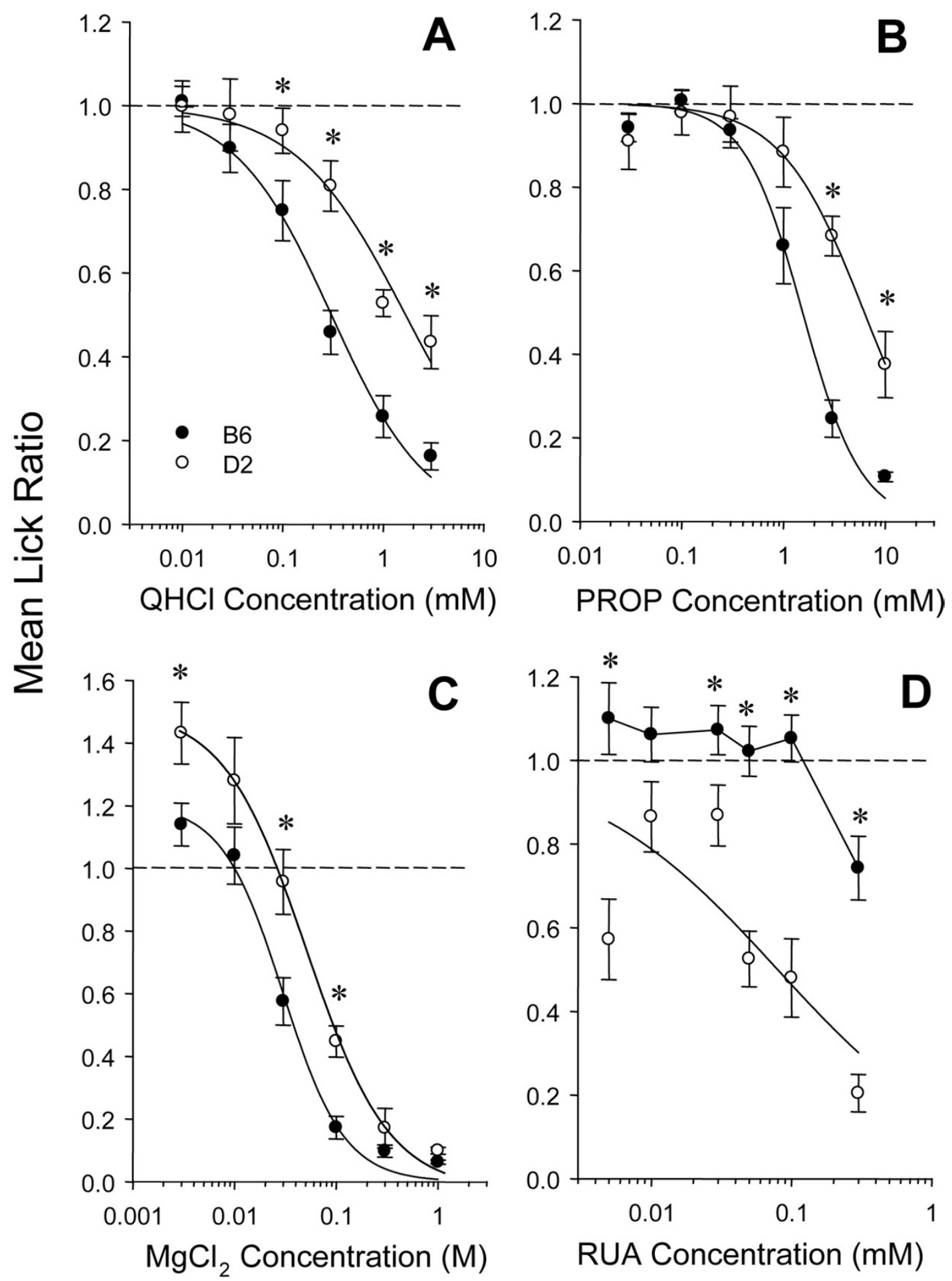

Figure 3

Lick ratios (mean \pm SE) for $B 6$ and D2 mice to concentration series of $\mathrm{QHCl}(\mathrm{A}), \mathrm{PROP}(\mathrm{B}), \mathrm{MgCl} 2(\mathrm{C})$, and $\mathrm{RUA}(\mathrm{D})$ ). The dotted lines on each graph represent a ratio score of 1.0 , which indicates a lick rate equal to that of water. Asterisks identify significant strain effects at particular concentrations, as indicated by planned comparisons $(p<0.0 \mathrm{I})$. Lick ratios for each strain generally decreased with increasing concentration; B6 made fewer licks than D2 mice to high concentrations of $Q H C l(A)$ and PROP (B), and to both low and concentrations of $\mathrm{MgCl}_{2}(\mathrm{C})$. D2 mice made fewer licks than B6 mice at almost all concentrations of RUA (D). 

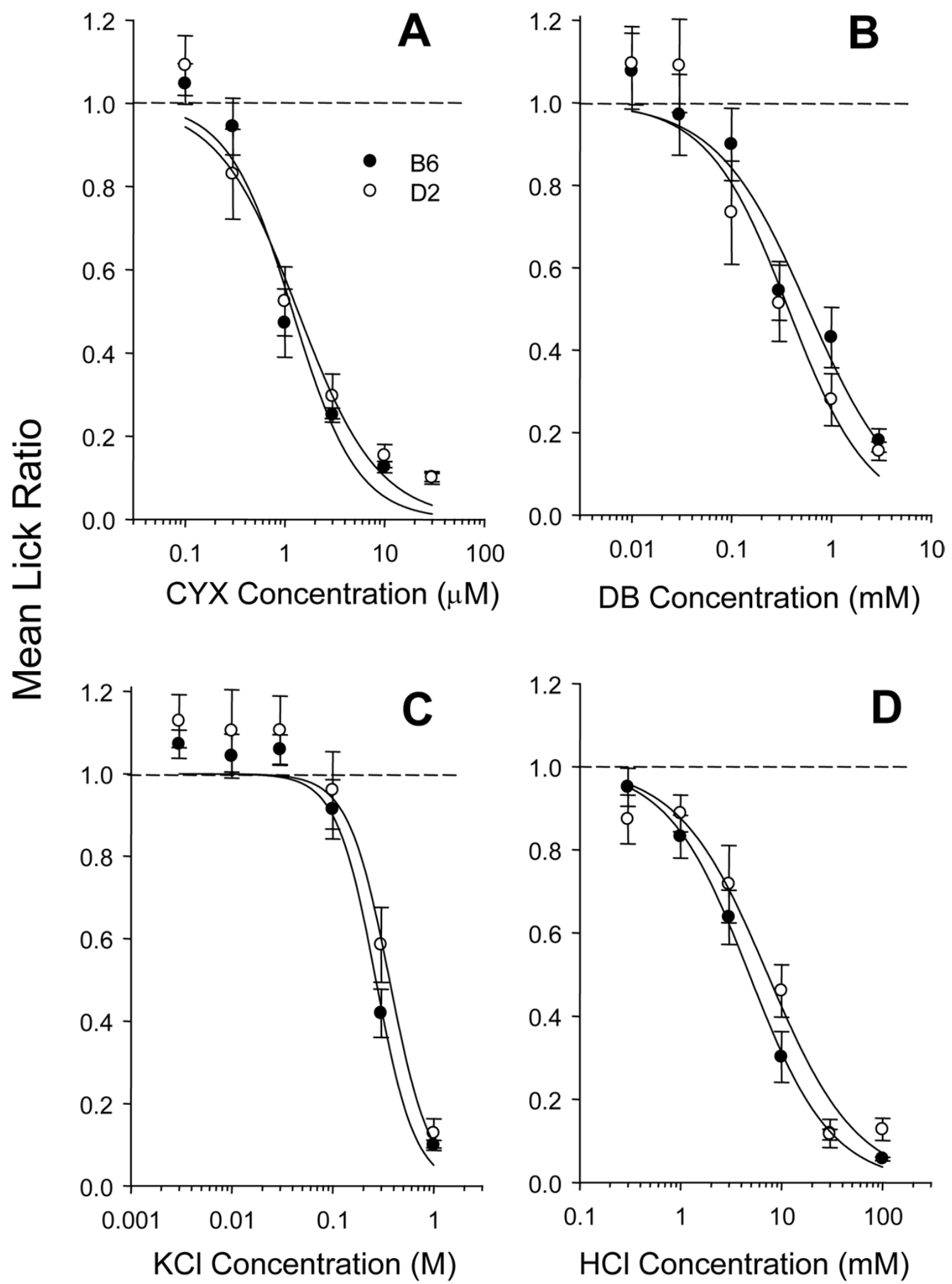

Figure 4

Lick ratios (mean $\pm S E$ ) for B6 and D2 mice to concentration series of CYX (A), DB (B), $\mathrm{KCl}(C)$, and $\mathrm{HCl}(\mathrm{D})$. The dotted lines on each graph represent a ratio score of $\mathrm{I} .0$, which indicates a lick rate equal to that of water. Lick ratios for each strain decreased with increasing concentration. The strains did not differ significantly for any of these compounds. 
Table 2: Mean \% trials completed by stimulus order. A trial was considered to be complete as long as a mouse took a single lick. After I 20 s had elapsed without a lick, a given trial was considered over, and the next trial began. B6 mice completed significantly more trials (out of a possible 24 per session) than did D2 mice across all three stimuli with which those mice were tested.

\begin{tabular}{|c|c|c|c|c|c|}
\hline & & $n$ & Stim I & Stim 2 & Stim 3 \\
\hline Strain & Gender & & & & \\
\hline \multirow[t]{2}{*}{ B6 } & Female & 15 & 96.9 & 94.6 & 96.0 \\
\hline & Male & 15 & 93.1 & 91.2 & 90.6 \\
\hline \multirow[t]{2}{*}{ D2 } & Female & 17 & 96.6 & 93.6 & 97.2 \\
\hline & Male & 13 & 93.4 & 88.6 & 94.6 \\
\hline
\end{tabular}

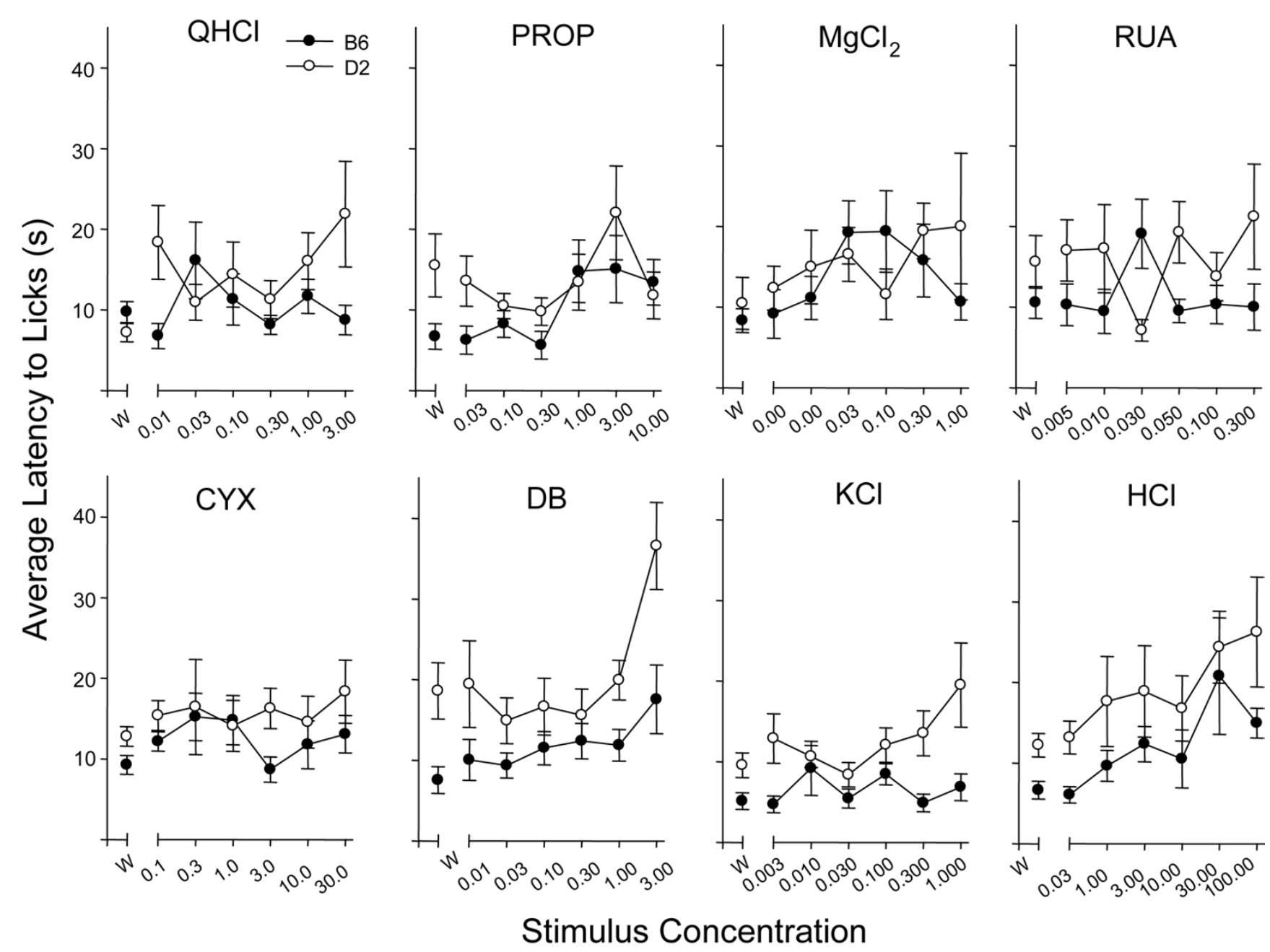

\section{Figure 5}

Strain comparison of latency to initiate taste trials of all eight stimuli. $W=$ water trials. Latencies are means $( \pm \mathrm{SE})$ of the median latencies for individual mice. A significant strain difference was found only for $\mathrm{KCl}$. Effects of concentration were found for $\mathrm{DB}$ and $\mathrm{HCl}$. 
used in this study, will lick water at a maximal rate, making an appetitive response difficult to discern. However, Dotson and Spector [25] demonstrated that waterrestricted mice of some strains will lick certain concentrations of appetitive stimuli (e.g., sucrose and glycine) at a higher rate than water. In our study, water licking rates during the $\mathrm{MgCl}_{2}$ test session did not significantly differ for those collected during testing with other stimuli. At higher concentrations (0.3-1.0 mM), $\mathrm{MgCl}_{2}$ was strongly avoided by both strains. This stimulus is perceived as having both a salty and bitter taste to humans [48]; in neural recordings with macaques it generally correlates with other bitters [49]. It is possible that at lower concentrations it is preferred over distilled water by some strains of mice for its salt taste component. $\mathrm{MgCl}_{2}$ is an intriguing candidate for which to determine possible Tas2r linkage; it evokes a strong anterior tongue-related neural response [50], which is a region that does not include strong T2R expression.

RUA is a non-toxic acetylated sugar; substantial variation in intake levels among inbred mouse strains have been shown for RUA as well another acetylated sugar, sucrose octaacetate (SOA) $[11,51,52]$. Sensitivity to SOA is determined by allelic variation at Soa, a locus linked to $\operatorname{Pr} p$ and the Tas $2 r$ cluster (e.g., $[38,53])$. A separate locus, Rua, was proposed to control aversion to RUA. In view of the close chemical similarity of RUA and SOA, and given identical inbred strain distribution patterns (SDPs), a more parsimonious explanation is that Soa and Rua are identical loci $[13,30]$. In our experiment, RUA taste sensitivity provides an example where D2 mice display greater levels of avoidance than $\mathrm{B} 6$ mice, demonstrating the specific nature of the bitter avoidance response in these two strains.

B6 and D2 mice did not significantly differ in taste sensitivity to $\mathrm{DB}, \mathrm{KCl}, \mathrm{HCl}$ and $\mathrm{CYX}$. The non-difference for CYX is especially interesting in that there are several coding-region polymorphisms in the Tas2r105 receptor (initially called T2R5) gene between these strains [41]; ); this receptor is activated by CYX in diverse in vitro assays, and a shift in the concentration-response function indicates that the $\mathrm{B} 6$ isoform is less sensitive [41]. This finding has led to the erroneous conclusion that $\mathrm{B} 6$ mice "cannot detect cycloheximide" (e.g., [54]). In fact, our finding that D2 and B6 mice do not differ significantly in taste-based aversion of CYX (Fig. 4) supports the previous finding that these strains do not differ in consumption [12]; see Fig. 3B and 3C). Additionally, CYX evokes a peripheral (glossopharyngeal) nerve response in $\mathrm{B} 6$ mice comparable to that evoked by PROP [18]. It is likely that other T2Rs, or T2R-independent mechanisms, contribute to the behavioral response in $\mathrm{B} 6$ mice and mask any potential difference produced by the polymorphic receptor. Alternatively, it is possible that a subtle, yet significant, strain difference might be detected with the testing of a larger sample of mice, or with the use of a different procedure such as threshold detection (e.g., [17]).

Our results point to the utility of these common inbred strains and their associated genetic resources, such as the BXD strains, for investigation into the genetic mechanisms of taste. Although behavioral sensitivity to bittertasting stimuli has been linked to the Tas $2 r$ family of bitter taste receptor genes, both by positional or functional studies, compelling questions remain about the peripheral and central organization of bitter taste and the relative contributions of individual genes to specific taste sensitivities.

\section{Methods \\ Mice}

A total of 60 male and female mice (Mus musculus) from inbred strains were used in these experiments: 30 from each inbred strain (B6 and D2). Mice were tested at an average age of 3.5 months, and were age-matched between strains in each test group. Table 1 lists the number of mice tested in each experiment. Roughly equal numbers of $\mathrm{B} 6$ and $\mathrm{D} 2$ mice were tested with up to 3 different stimuli over a two-week period. Mice were obtained directly from the Jackson Laboratory (Bar Harbor, ME), or were derived (first generation) from mice obtained from Jackson Laboratory. Mice were housed in plastic home cages $(28 \times 17.5 \times 13 \mathrm{~cm})$ with stainless steel wire lids. Food (Teklad 8640 rodent diet) and water were available ad lib. Immediately prior to water deprivation, the mean weight of B6 mice was $20.1 \mathrm{~g}$ (females) and $27.4 \mathrm{~g}$ (males); the mean weight of D2 mice was $21.6 \mathrm{~g}$ (females) and $26.2 \mathrm{~g}$ (males).

\section{Apparatus}

Mice were tested daily in the Davis MS-160 automated gustometer (DiLog Instruments, Inc., Tallahassee, FL). The test chamber consisted of a plastic rectangular cage $(30 \times 14.5 \times 18 \mathrm{~cm})$ with a wire mesh floor; an oval opening centered in the front wall allows access to water or taste solutions contained in leak-proof sipper tubes. Fluid access is restricted by a computer-operated shutter.

Trials began with the opening of the shutter and ended 5 $s$ after the mouse made its first lick on the drinking spout (see Procedure). Licks were counted with a high-frequency AC contact circuit. Failure to initiate a lick within $120 \mathrm{~s}$ also ended a trial, although such "zero lick" trials were ignored in analyses of lick rate as the failure to initiate licking could not be ascribed to orosensory factors. In between trials, a platform upon which the stimulus bottles were mounted was advanced to a new position. The inter-trial interval was held constant at $10 \mathrm{~s}$. The test session ended after the completion of 29 trials. 


\section{Solutions}

The taste stimuli used in these experiments were made from reagent-grade chemicals: 6-n-propylthiouracil (PROP), cycloheximide (CYX), raffinose undecaacetate (RUA), magnesium chloride $\left(\mathrm{MgCl}_{2}\right)$, potassium chloride $(\mathrm{KCl})$, quinine hydrochloride $(\mathrm{QHCl})$, denatonium benzoate (DB) and hydrochloric acid ( $\mathrm{HCl}$ ) (Sigma Aldrich Corp.; St. Louis, MO). Multiple concentrations of each solution were made fresh daily using distilled water, and all taste stimuli were presented at room temperature (concentrations are listed in Table 1).

\section{Brief-access tests}

Water-deprived mice were trained to lick water in the gustometer and subsequently tested with a six-concentration series of a taste stimulus. Mice were water-deprived for 24 $\mathrm{h}$ prior to the first day of training, and from that point on were restricted to water consumed during the training or testing session (approximately $1.5 \mathrm{ml}$ per session). On the first training day, mice were placed in the test chamber and given access to distilled water for $20 \mathrm{~min}$. Most mice took at least 100 licks from the drinking spout in this first session. On the second training day, access was restricted to $5 \mathrm{~s}$ trials. Water was delivered at random from one of four water tubes, and mice had the opportunity to initiate up to 16 trials. Testing with the first bitter stimulus occurred on days 3 and 4 . Six concentrations of the stimulus plus water were delivered using a randomized block design. Twenty-four trials were divided into 3 blocks of 8; within each block, each concentration of the stimulus plus two water trials were presented in a random order. Although we have previously determined that most mice are sated after 24 5-s trials of both stimulus and water, a final block of five consecutive water trials were given in order to allow the thirstiest mice to rehydrate. Licking in these additional trials was not analyzed. In sum, each test session provided three possible data points per stimulus concentration, and six for water trials. The order of all trials was randomized anew for each mouse and the position of bottles on the gustometer was randomized each day. Finally, mice of both strains were tested in a random order each day.

After testing on day 4, mice received ad lib water in their home cages for 48 hours (over the weekend), followed by a second 24-h water deprivation prior to a single training session and consecutive two-day tests with two additional stimuli, conducted as described above. We tested 7 "squads" of mice this way, until testing of 10 mice from either strain for each of eight stimuli was completed (see Table 1).

\section{Data analysis of behavioral tests}

The number of licks for each stimulus trial (each concentration being presented twice per mouse per session), plus water test trials, were averaged across the two test days for each individual mouse. These data were then reported as lick ratios (LR: average number of licks to stimulus / average number of licks during water test trial) in order to standardize for possible strain differences in water lick rate. Lick ratios thus range from a hypothetical zero (complete avoidance) to 1.0 (or greater). A ratio equal to zero was not possible because zero lick trials were not included in this analysis. Concentration-response functions were fit with a two-parameter logistic function:

$$
f(x)=\frac{1}{1+(x / c) b}
$$

Where $x$ is the concentration of stimulus, $c$ is the concentration evoking half-maximal avoidance (i.e. lick ratio $=$ $0.5)$ and $b$ is the slope. Fitting such curves provides a single parameter $(c)$ that is sensitive to shifts in the concentration-response function, as potentially resulting from strain differences. For lick ratios in response to $\mathrm{MgCl}_{2}$, a three-parameter function was used; the additional parameter $a$ was used to calculate an asymptotic maximum > 1.0 , since lick ratios to the lowest concentration $(0.003 \mathrm{M})$ of this tended to be greater than $\sim 1.0$, especially in D2 mice (see Figure 1). For group comparisons, $c$ values were log transformed; strain values presented are therefore geometric means.

All relevant variables were analyzed using a general linear model: repeated measures (concentration) with betweensubjects factors (strain, gender) and planned comparisons (LSD) at single concentrations based on the expectation of strain differences (Statistica software, StatSoft, inc., Tulsa, Oklahoma). Latency data (median latency) was log transformed for ANOVA. The statistical rejection criterion $(\alpha)$ for all tests was set a priori at the 0.01 level for main effects.

\section{Authors' contributions}

JB and SR collected and analyzed the behavioral data. JB and SM drafted the manuscript. JB, TN, and SM conceived of the study, participated in its design, and edited the manuscript. All authors read and approved the final manuscript.

\section{Acknowledgements}

The authors thank Aldan Shank for technical assistance with the behavioral studies and David V. Smith for comments on an earlier draft of the manuscript. This study was supported by grants from the National Institute on Deafness and Other Communication Disorders (DC05786 to SM,

DC04935 to JB), a Program Enrichment Fellowship from the University of Maryland, Baltimore (TN) and by the University of Tennessee Health Sciences Center (JB). 


\section{References}

I. Chesler EJ, Lu L, Wang J, Williams RW, Manly KF: WebQTL: rapid exploratory analysis of gene expression and genetic networks for brain and behavior. Nat Neurosci 2004, 7(5):485-486

2. Glazier AM, Nadeau JH, Aitman TJ: Finding genes that underlie complex traits. Science 2002, 298(5602):2345-2349.

3. Tecott LH: The genes and brains of mice and men. Am J Psychiatry 2003, I60(4):646-656.

4. Shirley RL, Walter NA, Reilly MT, Fehr C, Buck KJ: Mpdz is a quantitative trait gene for drug withdrawal seizures. Nat Neurosci 2004, 7(7):699-700.

5. Hitzemann R, Hitzemann B, Rivera S, Gatley J, Thanos P, Shou LL, Williams RW: Dopamine D2 receptor binding, Drd2 expression and the number of dopamine neurons in the $B X D$ recombinant inbred series: genetic relationships to alcohol and other drug associated phenotypes. Alcohol Clin Exp Res 2003, 27(I): I-II

6. Kirstein SL, Davidson KL, Ehringer MA, Sikela JM, Erwin VG, Tabakoff $B$ : Quantitative trait loci affecting initial sensitivity and acute functional tolerance to ethanol-induced ataxia and brain cAMP signaling in BXD recombinant inbred mice. J Pharmacol Exp Ther 2002, 302(3): I 238-1245.

7. Van Zant G, de Haan G: Genetic control of lifespan: studies from animal models. Expert Rev Mol Med 1999, I999: I- I2.

8. Williams RW, Gu J, Qi S, Lu L: The genetic structure of recombinant inbred mice: high-resolution consensus maps for complex trait analysis. Genome Biol 200 I, 2(I I):RESEARCH0046.

9. Williams RW, Holdener BC, Angel JM, Oakey R, Hunter KW: Encyclopedia of the mouse genome VII. Mouse chromosome 7 Mamm Genome 1998, 8 Spec No:SI36-59.

10. Lu L, Airey DC, Williams RW: Complex trait analysis of the hippocampus: mapping and biometric analysis of two novel gene loci with specific effects on hippocampal structure in mice. J Neurosci 200I, 2 I (I 0):3503-35I4.

II. Lush IE: The genetics of tasting in mice IV. The acetates of raffinose, galactose and beta-lactose. Genet Res 1986 42(2): I I 7-23.

12. Lush IE, Holland G: The genetics of tasting in mice. V. Glycine and cycloheximide. Genet Res 1988, 52(3):207-212

13. Lush IE, Hornigold N, King P, Stoye JP: The genetics of tasting in mice. VII. Glycine revisited, and the chromosomal location of Sac and Soa. Genet Res 1995, 66(2): 167-174.

14. Peirce JL, Lu L, Gu J, Silver LM, Williams RW: A new set of BXD recombinant inbred lines from advanced intercross populations in mice. BMC Genet 2004, 5(I):7.

15. Bachmanov AA, Reed DR, Tordoff MG, Price RA, Beauchamp GK Intake of ethanol, sodium chloride, sucrose, citric acid, and quinine hydrochloride solutions by mice: a genetic analysis. Behav Genet 1996, 26(6):563-573.

16. Glendinning JI, Gresack J, Spector AC: A high-throughput screening procedure for identifying mice with aberrant taste and oromotor function. Chem Senses 2002, 27(5):46 |-474.

17. Eylam S, Spector AC: The effect of amiloride on operantly conditioned performance in an $\mathrm{NaCl}$ taste detection task and $\mathrm{NaCl}$ preference in C57BL/6] mice. Behav Neurosci 2002, I I6(I): I49-159.

18. Danilova V, Hellekant G: Comparison of the responses of the chorda tympani and glossopharyngeal nerves to taste stimul in C57BL/6J mice. BMC Neurosci 2003, 4(I):5.

19. Kusakabe $Y$, Miura H, Hashimoto R, Sugiyama C, Ninomiya $Y$, Hino A: The neural differentiation gene Mash-I has a distinct pattern of expression from the taste reception-related genes gustducin and TIR2 in the taste buds. Chem Senses 2002 , 27(5):445-45I.

20. Frank ME, Blizard DA: Chorda tympani responses in two inbred strains of mice with different taste preferences. Physiol Behav 1999, 67(2):287-297.

21. Blizard DA, Kotlus B, Frank ME: Quantitative trait loci associated with short-term intake of sucrose, saccharin and quinine solutions in laboratory mice. Chem Senses 1999 24(4):373-385.

22. Kotlus BS, Blizard DA: Measuring gustatory variation in mice: a short-term fluid-intake test. Physiol Behav 1998, 64(I):37-47.

23. Eylam S, Spector AC: Taste discrimination between $\mathbf{N a C l}$ and $\mathrm{KCl}$ is disrupted by amiloride in inbred mice with amiloride- insensitive chorda tympani nerves. Am J Physiol Regul Integr Comp Physiol 2005, 288(5):RI 36I-8.

24. Eylam S, Spector AC: Stimulus processing of glycine is dissociable from that of sucrose and glucose based on behaviorally measured taste signal detection in Sac 'taster' and 'nontaster' mice. Chem Senses 2004, 29(7):639-649.

25. Dotson $C D$, Spector $A C$ : The relative affective potency of glycine, L-serine and sucrose as assessed by a brief-access taste test in inbred strains of mice. Chem Senses 2004, 29(6):489-498.

26. McClearn GERDA: Differences in alcohol preference among inbred strains of mice. J Stud Alcohol 1959, 20:691-695.

27. Fuller JL: Single-locus control of saccharin preference in mice. J Hered 1974, 65(I):33-36.

28. Lush IE: The genetics of tasting in mice. III. Quinine. Genet Res 1984, 44(2): $151-160$

29. Ninomiya Y, Sako N, Funakoshi M: Strain differences in amiloride inhibition of $\mathrm{NaCl}$ responses in mice, Mus musculus. I Comp Physiol [A] 1989, I 66(I): I-5.

30. Harder DB, Capeless CG, Maggio JC, Boughter JJ, Gannon KS, Whitney G, Azen EA: Intermediate sucrose octaacetate sensitivity suggests a third allele at mouse bitter taste locus Soa and Soa-Rua identity. Chem Senses 1992, 17:391-401

31. Spielman Al, Huque T, Whitney G, Brand JG: The diversity of bitter taste signal transduction mechanisms. Soc Gen Physiol Ser 1992, 47:307-324.

32. Glendinning J: Is the bitter rejection response always adaptive? Physiol Behav 1994, 56(6): 1217-1227.

33. Nelson TM, Munger SD, Boughter JDJ: Taste sensitivities to PROP and PTC vary independently in mice. Chem Senses 2003, 28(8):695-704

34. Boughter JDJ, St John SJ, Noel DT, Ndubuizu O, Smith DV: A briefaccess test for bitter taste in mice. Chem Senses 2002 , 27(2): | 33-142.

35. Rhinehart-Doty JA, Schumm J, Smith JC, Smith GP: A non-taste cue of sucrose in short-term taste tests in rats. Chem Senses 1994, | 9(5):425-43|

36. St John SJ, Boughter JDJ: The contribution of taste bud populations to bitter avoidance in mouse strains differentially sensitive to sucrose octa-acetate and quinine. Chem Senses 2004 29(9):775-787

37. Harder DB, Whitney G: A common polygenic basis for quinine and PROP avoidance in mice. Chem Senses 1998, 23(3):327-332.

38. Adler E, Hoon MA, Mueller KL, Chandrashekar J, Ryba NJ, Zuker CS: A novel family of mammalian taste receptors. Cell 2000, I 00(6):693-702.

39. Matsunami H, Montmayeur JP, Buck LB: A family of candidate taste receptors in human and mouse. Nature 2000 , 404(6778):60I-604

40. Azen EA, Davisson MT, Cherry M, Taylor BA: Prp (proline-rich protein) genes linked to markers Es- 12 (esterase- I2), Ea- 10 (erythrocyte alloantigen), and loci on distal mouse chromosome 6. Genomics 1989, 5(3):4I5-422.

4I. Chandrashekar J, Mueller KL, Hoon MA, Adler E, Feng L, Guo W Zuker CS, Ryba NJ: T2Rs function as bitter taste receptors. Cell 2000, I00(6):703-7II

42. Behrens M, Brockhoff A, Kuhn C, Bufe B, Winnig M, Meyerhof W The human taste receptor hTAS2RI 4 responds to a variety of different bitter compounds. Biochem Biophys Res Commun 2004, 3 I 9(2):479-485

43. Bufe B, Hofmann T, Krautwurst D, Raguse JD, Meyerhof W: The human TAS2R 16 receptor mediates bitter taste in response to beta-glucopyranosides. Nat Genet 2002, 32(3):397-40I.

44. Boughter JDJ, Harder DB, Capeless CG, Whitney G: Polygenic determination of quinine aversion among mice. Chem Senses 1992:427-434.

45. Boughter JDJ, Whitney G: Behavioral specificity of the bitter taste gene Soa. Physiol Behav 1997, 63(I): 101-108.

46. Chen $Y$, Herness MS: Electrophysiological actions of quinine on voltage-dependent currents in dissociated rat taste cells. Pflugers Arch 1997, 434(3):215-226.

47. Caicedo A, Pereira E, Margolskee RF, Roper SD: Role of the G-protein subunit alpha-gustducin in taste cell responses to bitter stimuli. J Neurosci 2003, 23(30):9947-9952.

48. Delwiche JF, Buletic Z, Breslin PA: Covariation in individuals' sensitivities to bitter compounds: evidence supporting multiple 
receptor/transduction mechanisms. Percept Psychophys 200I, 63(5):76I-776.

49. Scott TR, Giza BK, Yan J: Gustatory neural coding in the cortex of the alert cynomolgus macaque: the quality of bitterness. J Neurophysiol I999, 8I(I):60-7I.

50. Dahl M, Erickson RP, Simon SA: Neural responses to bitter compounds in rats. Brain Res 1997, 756(I-2):22-34.

5I. Warren RP, Lewis RC: Taste polymorphism in mice involving a bitter sugar derivative. Nature 1970, 227(5253):77-78.

52. Lush IE: The genetics of tasting in mice. I. Sucrose octaacetate. Genet Res 1981, 38(I):93-95.

53. Capeless CG, Whitney G, Azen EA: Chromosome mapping of Soa, a gene influencing gustatory sensitivity to sucrose octaacetate in mice. Behav Genet 1992, 22(6):655-663.

54. Scott K: The sweet and the bitter of mammalian taste. Curr Opin Neurobiol 2004, 14(4):423-427.

55. Mueller KL, Moon MA, Erlenbach I, Chandrashekar J, Zuker CS, Ryba NJ: The receptors and coding logic for better taste. Nature 2005, 434(7030):225-9.

56. Nelson TM, Munger SD, Boughter JD Jr: Haplotypes at the Tas2r locus on distal chromosome 6 vary with quinine taste sensitivity in inbred mice. BMC Genet 2005, 6(I):32.

Publish with Biomed Central and every scientist can read your work free of charge

"BioMed Central will be the most significant development for disseminating the results of biomedical research in our lifetime. "

Sir Paul Nurse, Cancer Research UK

Your research papers will be:

- available free of charge to the entire biomedical community

- peer reviewed and published immediately upon acceptance

- cited in PubMed and archived on PubMed Central

- yours - you keep the copyright 